\title{
Feasibility and Safety of Endometrial Injection of Autologous Bone Marrow Mesenchymal Stem Cells in Mares
}

\author{
Marco Antonio Alvarenga*, Marcio Teoro do Carmo, Lorenzo Garrido Segabinazzi, \\ Mydian Daroz Guastali, Leandro Maia, Fernanda Cruz Landim- Alvarenga
}

Department of Animal Reproduction and Veterinary Radiology, São Paulo State University-UNESP, Botucatu, São Paulo, Brazil

\section{A R T I C L E I N F O}

\section{Article history:}

Received 24 November 2015

Received in revised form 28 February 2016

Accepted 4 March 2016

Available online 12 March 2016

\section{Keywords:}

Endometritis

Endometriosis

Stem-cell

Mare

Fibrosis

\begin{abstract}
A B S T R A C T
Chronic degenerative endometritis (CDE) is an important cause of fertility problems in older mares. It is estimated that $30 \%$ of mares breeding are over 18 years old and the high value of their progeny encourages the use of these animals in assisted reproduction procedures. Currently, cell-based therapies are broadly used in human and veterinary regenerative medicine and have been showed a good effect on the treatment of liver fibrosis. Thus, the present study aimed to evaluate the feasibility and safety of endometrial injection of autologous bone marrow MSCs in mares. Mares were examined by transrectal ultrasound and the endometrial stem cells injections performed during diestrous, using injection needles coupled to a teflon catheter through the biopsy channel of a flexible endoscope. After treatment clinical evaluations (heart reat, respiratory rate, staining of the mucosa, capillary refill time, body temperature and lameness score) were performed daily during seven days. The intrauterine fluid and endometrial edema was evaluated before, 24 and 48 hours after the procedure by ultrasonographic exams and the inflammatory infiltrate (polymorphonuclear cells and mononuclear cells) and degree of fibrosis by histological evaluations before (D0) and 15 (D15), 30 (D30) and 60 (D60) days after endometrial injections. The results were evaluated by Kolmogorov-Smirnov and Kruskal-Wallis test followed by Dunn test and for fertility rates was used Chi-square, considering a $5 \%$ significance level. Neither clinical alteration was observed in mares after treatment, as well as, intrauterine fluid and endometrial edema were not detected in any mare before and after cell therapy. After cell therapy, significantly more PMNs were found in D15 biopsies, however, these cells were not observed in D30 and D60 biopsies. No worsening on the histological architecture after treatment was observed in any mare. In conclusion, the results of this study showed that endometrial hysteroscopic injections of stem cells in mares is a safe procedure.
\end{abstract}

(c) 2016 Elsevier Inc. All rights reserved.

\section{Introduction}

It is estimated that $30 \%$ of mares breeding are over 18 year olds [1], and the high value of their progeny encourages the use of these animals in embryo transfer programs,

\footnotetext{
* Corresponding author at: Marco Antonio Alvarenga, Departamento de Reprodução Animal e Radiologia Veterinária, FMVZ, UNESP, Distrito de Rubião Junior, s/nº $18618-970$, Botucatu, São Paulo, Brazil.

E-mail address: malvarenga@fmvz.unesp.br (M.A. Alvarenga).
}

to obtain a larger number of offsprings to these animals. However, a high percentage of these old mares have fertility problems related to age. In this context, chronic degenerative endometritis (CDE) is an important cause to fertility problems in these mares [2,3].

Chronic degenerative endometritis is a degenerative alteration of uterine glands and surrounding stroma, characterized by a periglandular and stromal endometrial fibrosis, including glandular alterations in the fibrotic foci [4]. The periglandular arrangement of myofibroblasts and 
extracellular matrix deposition is important characteristics of $\mathrm{CDE}$ [5]. Endometrial fibrosis is a progressive condition, which tends to worsen with age [6].

Currently, cell-based therapies are broadly used in human and veterinary regenerative medicine [7-9]. In equines, such therapies aim to use stem cells to recover cartilage [10] and tendinous tissues [11], demonstrating numerous biological properties of mesenchymal stem cells (MSCs). In particular, one recent study demonstrated that stem cells infused into the uterine lumen became established in the periglandular area of the uterine endometrium [12], showing that stem cell therapy is a promising alternative for endometrial fibrosis and others uterine diseases in mares because of the high capacity for selfregeneration, the low immunogenicity, and the paracrine, anti-inflammatory, immunomodulatory, antiapoptotic, and neuroprotective effects of MSCs [13]. Moreover, other studies reported that MSCs transplantation has a good effect on the treatment of liver fibrosis [14-17].

Thus, the present study aimed to evaluate the feasibility and safety of endometrial injection of autologous bone marrow MSCs in mares.

\section{Materials and Methods}

\subsection{Animals}

Sixteen crossbred mares, aging 15-24 years, weighing between 350 and $500 \mathrm{~kg}$, from the Department of Animal Reproduction and Veterinary Radiology, São Paulo State University, UNESP Botucatu, SP/Brazil were used. All animals showed good body condition (6.0-8.0) according to Henneke et al [18], with a reproductive history of subfertility and endometrium classified as grades II-b and III on histology, characterized by moderate to severe degenerative process according to the classification proposed by Kenney and Doig [19]. Mares were feed with $2.0 \mathrm{~kg}$ of concentrated balanced grain, water, and mineral salt ad libitum.

\subsection{MSC Harvesting, Culture, and Processing}

Bone marrow aspiration puncture was performed according to the modified methodology described by Barreira and Alves [20]. The animals remained standing were sedated with $0.5 \mathrm{mg} / \mathrm{kg}$ xylazine (Sedazine, Fort Dodger, USA), and a local anesthetic blockade (10-mL lidocaine hydrochloride, Xylestesin, Cristalia, Brazil) was performed on the puncture site. The puncture was performed on the fifth sternebra using a bone marrow biopsy needle for equines (Jamshidid model, 8-mm gauge, and $12 \mathrm{~cm}$ length). Bone marrow aspiration was performed using two $20-\mathrm{mL}$ syringes, containing Dulbecco's phosphate-buffered saline $(5 \mathrm{~mL})$ and heparin $(1 \mathrm{~mL})$ at 5,000 $\mathrm{IU} / \mathrm{mL}$. After harvesting, the bone marrow was filtered and centrifuged at $400 \mathrm{~g}$ for 10 minutes to remove the serum and fat.

The material obtained by centrifugation was resuspended in a 1:1 ratio in high-glucose Dulbecco's Modified Eagle Medium (DMEM) containing L-glutamine without serum (Gibco, USA) and transferred to another 15-mL tube containing four mlof Ficoll-Paque density gradient (density $1.077 \mathrm{~g} / \mathrm{mL}$-Amersham Biosciences) (Ficoll:medium dilution in a $1: 1$ ratio). These samples were then centrifuged at $400 \mathrm{~g}$ for 40 minutes at room temperature.

The halo located at the Ficoll-cell interface, which contained the MSCs, was resuspended in high-glucose DMEM medium. Material was centrifuged two more times at $400 \mathrm{~g}$ for 10 minutes to completely remove the Ficoll. The pellet was resuspended in $1 \mathrm{~mL}$ DMEM medium containing 10\% fetal bovine serum (FBS), and the cells were counted in a Neubauer chamber. The cells were then plated in $25-\mathrm{cm}^{2}$ flasks, containing $5 \mathrm{~mL}$ high-glucose DMEM 10\% FBS (Gibco, USA), $100 \mathrm{IU} / \mathrm{mL}$ penicillin, $100 \mu \mathrm{g} / \mathrm{mL}$ streptomycin (Pen Strep, Gibco, USA), and $3.0 \mu \mathrm{g} / \mathrm{mL}$ amphotericin B (Fungizone, Gibco, USA) and kept in a drying oven at $37.5^{\circ} \mathrm{C}$ and a $5 \% \mathrm{CO}_{2}$ humidified atmosphere. The growth medium was changed every 4 to 5 days, and replating was performed when a subconfluence of approximately $80 \%$ was reached.

\subsection{Evaluation of MSC Viability}

After obtaining cells at confluence, the medium was removed, and the cells were washed with Hanks' Balanced Salt Solution (HBSS, Gibco, USA). Then, $2 \mathrm{~mL}$ of trypsin (TrypLE Express, Gibco, USA), preheated at $37^{\circ} \mathrm{C}$ for $5 \mathrm{mi}-$ nutes, was added. The culture flask was mechanically stirred, the content was poured into a graduated tube, and $1 \mathrm{~mL}$ high-glucose DMEM 10\% FBS was added. The cells were then centrifuged at $400 \mathrm{~g}$ for 10 minutes, the supernatant was discarded, and the pellet was homogenized in new cell growth medium.

Cell viability was estimated using the Trypan blue (Gibco, USA) dye exclusion technique, diluting the cells in the staining medium at a 1:1 ratio. Analysis of cell viability was performed in a Neubauer chamber. The structures stained blue were classified as damaged cells, and those that were not stained were classified as intact cells.

The cells were plated at a concentration of $1 \times 10^{5}$ cells per culture flask, and $5 \mathrm{~mL}$ of the previously described growth medium was added.

\subsection{Characterization of MSCS}

The characterization of the MSCs at the primary culture was performed. The cells were resuspended in a concentration of $1 \times 10^{5}$ cells $/ \mathrm{mL}$ and marked with the superficial marker mouse antihorse CD44:FITC (MCA1082F, ABD Serotec, USA) used as positive marker and a rat marker antidog CD34:FITC (MCA2411F, ABD Serotec, USA) used as negative marker. The analyses were performed in flow cytometer (FACSCalibur BDTM115, BD, USA).

In order to check the origin of the MSCs isolated in primary culture, its differentiation in cells of mesodermic tissue was performed (bone cells, chondrocyte, and adipocyte). To induce the differentiation to the osteogenic lineage, Mesenchymal Stem Cell Osteogenesis Kit (Chemicon, Cat.SCR028) was used. To confirm these differentiation, the cells were marked with a solution of "Alizarin Red." The differentiation of the MSCs in the adipogenic lineage was induced using Mesenchymal Stem Cell Adipogenesis Kit (Chemicon, Cat.SCR020), then confirmed with the cells marker "Oil Red O." To differentiate the MSCs to the chondrogenic lineage, the STEMPRO Chondrogenesis 
Differentiation Kit (A10071-01) was used; these chondrocyte differentiation was confirmed marking the cells with "Alcian blue."

\subsection{Stem Cell Hysteroscopic Injection}

Each mare served as their own control to reduce a sampling effect on data analysis, and the moment before endometrial injection of stem cells was considerate as a control.

Mares were examined by rectal palpation and transrectal ultrasound once daily, and the endometrial injection of stem cells was performed during diestrous, showing no endometrial edema, uterine tone, and a visible corpus luteum in one of their ovaries. After endometrial stem cell injection, all mares were treated every 7 days with $1.5 \mathrm{~g}$ progesterone (IM) (BioRelease LAP4300, BetLabs, Lexington, KY) until 60 days after stem cells injection, to maintain a standard evaluation of the endometrial biopsies.

All intrauterine procedures were performed with sterilized equipment and the examiner wearing disposable palpation glove. For all intrauterine procedures, mares were restrained in examination stocks, and the perineum was aseptically scrubbed with a mild detergent, rinsed with clean water two times, and dried with paper towels. The mares were maintained on quadrupedal position, physically restrained, and sedated with detomidine ( $20 \mu \mathrm{g} / \mathrm{kg}$, IV; Dormosedan, Pfizer Animal Health Inc, Exton, PA). The administration of stem cells into the uterus was performed using injection needles coupled to a teflon catheter (GF252213, GFE do Brasil LTDA., Brazil) through the biopsy channel of a 2 meters flexible endoscope (Series 160 Olympus, Olympus Optical do Brasil Ltda, Brazil) (Fig. 1) connected with an endoscopy camera (Olympus OTV-S6, Olympus Optical do Brasil Ltda, Brazil). The endoscope was passed manually through the cervix into the uterine body. The uterus was insufflated with nonsterilized air to allow visualization of the entire endometrial surface. A concentration of $12 \times 10^{6}$ stem cells diluted in $6 \mathrm{~mL}$ of PBS was used. Then, injections of $0.5 \mathrm{~mL}$ of the cell solution $(1 \times$ $10^{6}$ stem cells) were administered at 12 different sites $1 \mathrm{~cm}$ apart approximately, following a horizontal line from the extremity of one uterine horn to the other (Figs. 2 and 3).

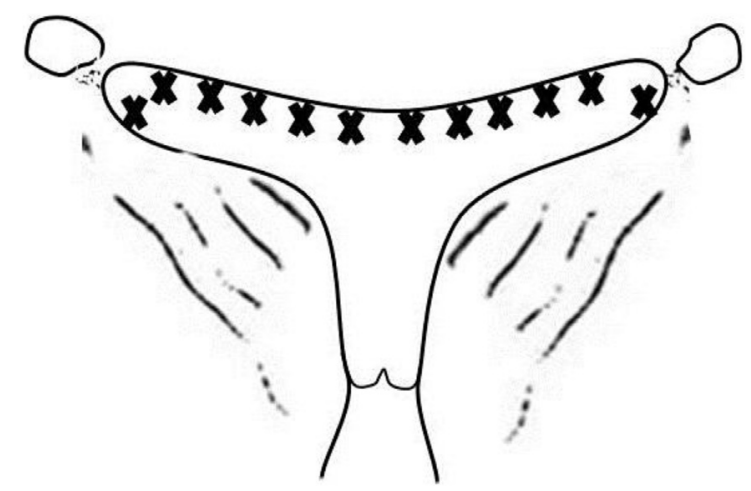

Fig. 2. Diagram showing the points to endometrial stem cell application.

\subsection{Sampling Strategy}

\subsubsection{Clinical Evaluations}

Before and after treatment, physical examinations were performed daily during 7 days, to evaluated possible systemic effects caused by stem cells hysteroscopic injection. For that were evaluated heart rate, respiratory rate, staining of the mucosa, capillary refill time, body temperature, and lameness score [21].

\subsubsection{Ultrasonographic Evaluations}

Transrectal ultrasound evaluations were performed before, 24, and 48 hours after cell therapy, for endometrial edema and intrauterine fluid accumulation observation. Absence or presence of fluid was recorded to detect the presence and measuring of uterine fluid accumulated in the region of the bifurcation of the uterine horns. The column of intrauterine fluid was measured in millimeters $(\mathrm{mm})$. Endometrial edema was classified as grades 0 to $3 \mathrm{ac}-$ cording to McCue et al [22].

\subsubsection{Uterine Biopsy}

Uterine biopsies were performed before (D0) and 15 (D15), 30 (D30), and 60 (D60) days after stem cells injection. Uterine biopsies were taken with alligator jaw biopsy forceps from the base of one uterine horn, using standard

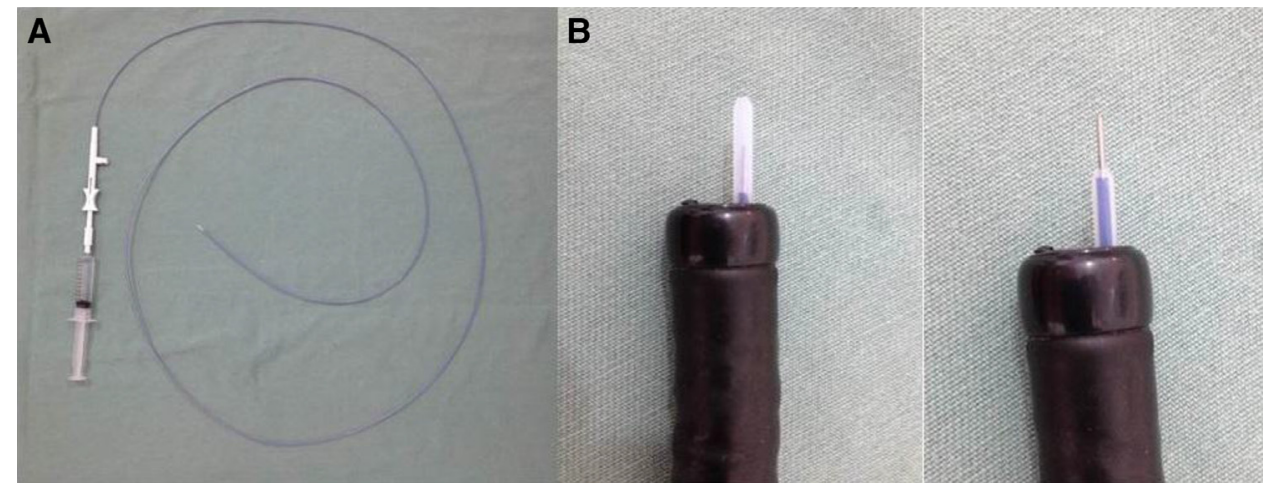

Fig. 1. (A) Injection needles coupled to a teflon catheter. (B) Sequence of a teflon catheter exposition in the biopsy channel of the endoscope and the needle exposition. 


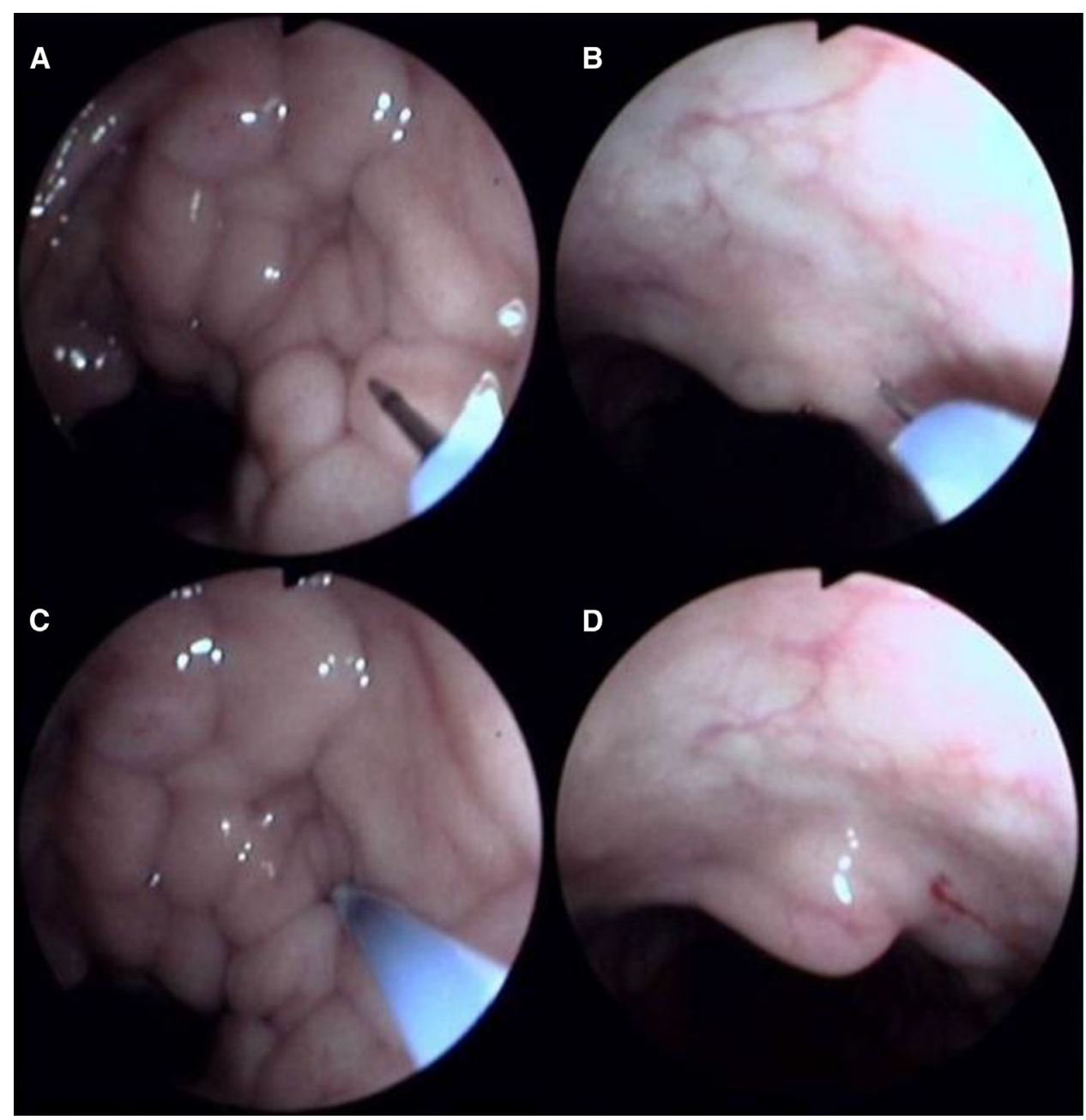

Fig. 3. Sequence of endometrial stem cell application: (A) showing the needle exposition; (B) needle inserted in the endometrium; (C) stem cell injection; and (D) local engorgement after injection.

procedures [23], fixed in Bouin's solution for 24 hours and were then kept in $70 \%$ ethanol before paraffin embedding.

\subsubsection{Histology}

Biopsies were embedded in paraffin, and specimen for histology was cut at a thickness of $5 \mu \mathrm{m}$ and stained with H\&E [23]. Samples evaluations were performed by an experience investigator without the samples identification, for to blind evaluator, using a light microscope $(1,000 \times)$.

Samples of D0 and D60 were evaluated according to their degree of fibrosis as proposed by Kenney and Doig [19] and observed if there was worsening on the endometrial architecture after treatment. The inflammatory infiltrate was observed in all samples (D0, D15, D30, and D60) on four randomly selected fields with intact blood vessels, intact epithelia, and no biopsy artifacts and classified using the criteria described by Maia et al [24] with some modifications. For the presence of polymorphonuclear cells (PMNs) and mononuclear cells in the stratum compactum and luminal epithelium, scores from 0 to 4 were established: 0 , none inflammatory infiltrate (any PMN per field); 1 , slight inflammatory infiltrate ( $<4$ PMNs per field); 2, slight to moderate (between 4 and 10 PMNs per field); 3, moderate (between 10 and 30 PMNs per field); 4, severe inflammatory infiltrate ( $>30$ PMNs per field).

\subsection{Statistical Analysis}

Dates of inflammatory infiltrate were evaluated using Kolmogorov-Smirnov normality test, to test its Gaussian distribution. Parametric continuous dates were compared for analysis of variance followed by the Tukey test and nonparametric dates, for Kruskal-Wallis test followed by the Dunns test. Significant differences were considered when $P<.05$.

\section{Results}

\subsection{Viability and Characterization of the MSCS}

The MSCs exhibited a fibroblastic morphology, with an average time of adherence to the culture plate of 5 days and 
an average confluence time of 22 days $\left(2.6 \times 10^{7}\right.$ cells at confluence). Cell viability, as evaluated by Trypan blue staining, was $95 \%$. Based on the immunophenotyping evaluation at the first passage, there was average staining for CD44 (91.43\%) and staining for CD34 (8.44\%).

\subsection{Clinical Evaluations}

Neither clinical alteration was observed in mares after treatment. All mares showed normal clinical patterns, and no horse lameness was observed in any mare.

\subsection{Ultrasonographic Examinations}

Changes on intrauterine fluid and endometrial edema were not detected in any mare before and after cell therapy $(P>.05)$.

\subsection{Histology}

In histological evaluations, any mare showed a worsening on the histological architecture after treatment. In D0 (before cell therapy), a light infiltrate of PMNs was observed in the stratum compactum. After cell therapy, significantly $(P<.05)$ more PMNs were found in D15 biopsies; however, these cells were not observed $(P<.05)$ in D30 and D60 biopsies. The infiltrated on endometrium of mononuclear cells in endometrial biopsies did not differ $(P$ $>.05$ ) between moments of biopsies (Fig. 4).

\section{Discussion}

The MSCs used in this study exhibited fibroblastoid morphology during the in vitro culture process, and this finding is consistent with the characteristics of mesenchymal cells, as demonstrated by Oshima et al [25]. The protocol used in the present study to isolate MSCs was effective, resulting in the recovery of cells that presented after culture staining for monoclonal antibodies to CD44 (92.03\% - mesenchymal cells) and staining for CD34 (7.97\%-hematopoietic cells), a result similar to the findings of Kern et al [26] and Zhu et al [27]. The staining of MSCs for CD34 and CD44 by flow cytometry in domesticated animals is possible due to the availability of specific monoclonal antibodies [28]. However, because of the low availability of specific antibodies for equine for CD44, canine antibodies were used in the present study, for which cross-reactivity was observed in previous studies [29]. Therefore, the MSCs from both present and previous studies $[27,30]$ were similarly characterized according to negative staining for CD34 and positive staining for CD44, as well as their capacity for adherence to the culture plate. In the cell differentiation test, the MSCs obtained from the bone marrow were capable of differentiating into chondrogenic, adipogenic, and osteogenic cell lineage, which confirms the results observed by Lima-Neto [29].

The absence of clinical alterations after stem cells endometrial injections shows that this procedure is safety. It agreeing with others studies using intraarticular administration of MSCs [31,32], intratendinous stem cells injection [33], multiple intravenous injections of MSCs [34], or intrathecal transplantation [13] that did not observe modification of clinical standards after procedures.

According to Ferrer [35], mares with delayed uterine clearance have in a significantly higher intrauterine fluid 24 hours but not 48 hours after hysteroscopic. However, fluid accumulation or endometrial edema was not observed in this study after hysteroscopic procedures.

The endometrial architecture did not worsen in mares after treatment with stem cells. Some studies [12,36] showed that the local use of stem cells into the uterus is beneficial to the endometrial architecture, confirming our observations that endometrial stem cells injections did not cause an increase of uterine fibroses. These findings are

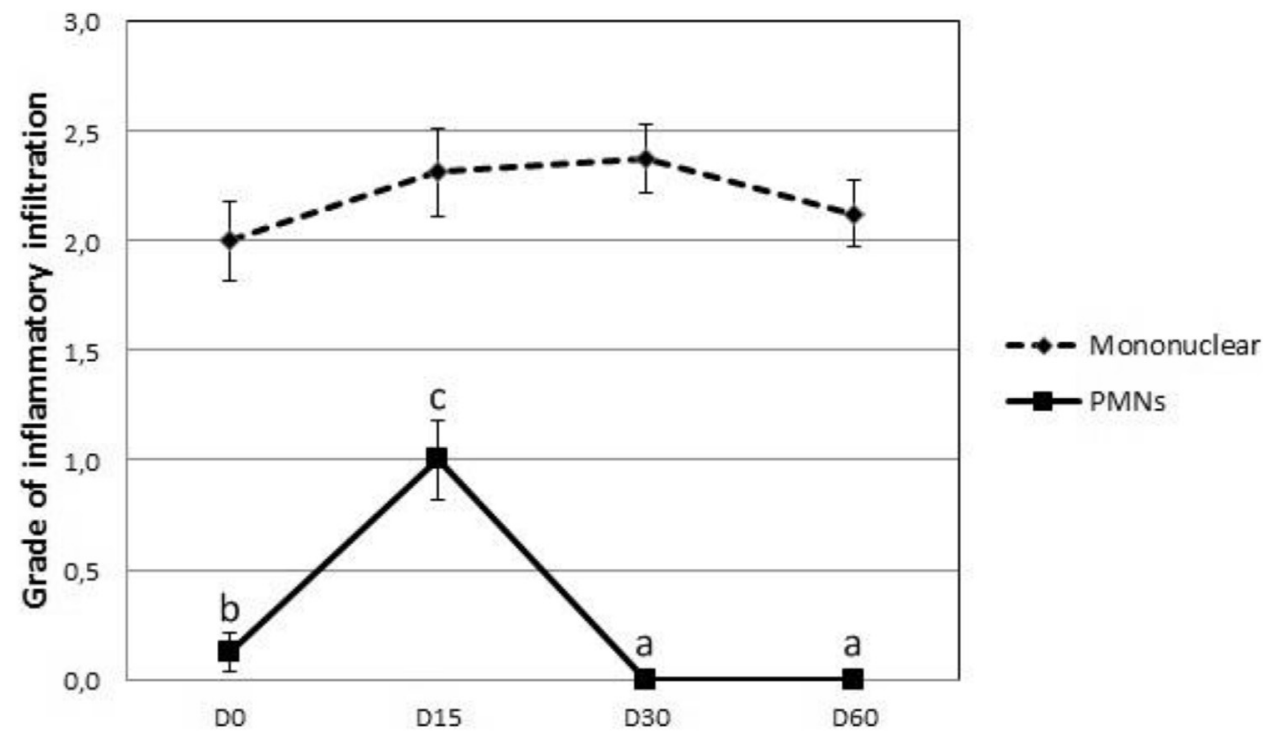

Fig. 4. Inflammatory infiltrate in biopsies before (D0), 15 (D15), 30 (D30), and 60 (D60) days after endometrial stem cell injections. Different superscript letters $\left({ }^{\mathrm{a}, \mathrm{b}, \mathrm{c}}\right)$ are significantly different $(P<.05)$. 
strengthened by the fact that the treatment with stem cells also benefits in tissue recovery tendon and bone-joint injuries in horses [10,11,32,33,37-42]. Likewise, a slight infiltration of PMNs 15 days after stem cells injections occurs in this study, suggesting a local reaction to MSCs injection. Del Bue [43] using allogeneic adipose-derived MSC mixed with autologous platelet-rich plasma for treatment of tendinitis in horses observed a mild edema and increased injection site pain in 50\% of the horses, 2 days after treatment. The authors proposed that intratendinous stem cell injection elicits mild tissue inflammation. Carrade et al [32] also observed that the main adverse effects related with intraarticular stem cell therapy in horses are also a transient inflammation. This mild tissue inflammatory infiltration was also observed in equine tendon at days 10 and 34 after MSC injection [33]. However, in our study, this inflammatory process was not present any more 30 days after MSCs injection.

Based on the results of the present study, we can conclude that endometrial injections of MSC are a safe procedure and the inflammatory response was short term, self-limiting and did not result in any consistent, clinically, or uterine disturb. These data provide essential preliminary information from which prospective clinical trials can be developed to determine the efficacy of this treatment for uterine diseases. Preliminary results using stem cells $[12,36]$ for treatment of endometrial fibrosis encourage further research in mares with this pathology.

\section{References}

[1] Alvarenga MA, Carmo MT. Biotecnologias em reprodução equina: o que há de novo para o veterinário de campo? Braz J Equine Med 2009;26:4-8.

[2] Ricketts SW, Alonso S. The effect of age and parity on the development of equine chronic endometrial disease. Equine Vet J 1991; 23:189-92.

[3] Hoffmann C, Ellenberger C, Mattos RC, Aupperle H, Dhein S, Stief B, Schoon HA. The equine endometrosis: new insights into the pathogenesis. Anim Reprod Sci 2009;111:261-78.

[4] Hoffmann C, Bazer FW, Klug E, Allen WR, Aupperle H, Ellenberger C, Schoon HA. Morphofunctional studies regarding the pathogenesis of the equine endometrosis with special emphasis on uterine secretions-preliminary results. Pferdeheilkunde 2003;19:666-9.

[5] Walter I, Handler J, Reifinger M, Aurich C. Association of endometrosis in horses with differentiation of periglandular myofibroblasts and changes of extracellular matrix proteins. Reproduction 2001; 121:581-6

[6] Woodward EM, Christoffersen M, Campos J, Squires EL, Troedsson MH. Susceptibility to persistent breeding-induced endometritis in the mare: relationship to endometrial biopsy score and age, and variations between seasons. Theriogenology 2012;78:495-501.

[7] Bhattacharya V, McSweeney PA, Shi Q Brubo B, Isgida A, Nash R, Storb RF, Sauvage LR, Hammond WP, Wu MH. Enhanced endothelialization and microvessel formation in polyester grafts seeded with CD34+ bone marrow cells. Blood 2000;95:581-5.

[8] Fang B, Shi M, Liao L, Yang S, Liu Y, Zhao RC. Systemic infusion of FLK! (+) mesenchymal stem cells ameliorate carbon tetrachlorideinduced liver fibrosis in mice. Transplantation 2004;78:83-8.

[9] Birgt AB, Honold J, Volker S, Martinna BB, Ulrich F, Rasokat RL. Transcoronary transplantation of progenitor cells after myocardial infarction. N Engl Med 2006;355:1222-32.

[10] Fortier LA, Smith RK. Evidence for stem cells in cartilage regeneration. AAEP Proc 2007;53:1207.

[11] Fortier LA, Smith RK. Regenerative medicine for tendinous and ligamentous injuries of sport horses. veterinary clinics. Equine Pract 2008;24:191-201.
[12] Mambelli LI, Winter GH, Kerkis A, Malschitzky E, Mattos RC, Kerkis I. A novel strategy of mesenchymal stem cells delivery in the uterus of mares with endometrosis. Theriogenology 2013;79:744-50.

[13] Maia L, Landim-Alvarenga FC, Taffarel MO, Moraes CN, Machado GF, Melo GD, Amorim RM. Feasibility and safety of intrathecal transplantation of autologous bone marrow mesenchymal stem cells in horses. BMC Vet Res 2015;11:63.

[14] XuJ, Chen G. The progress of between bone marrow mesenchymal stem cells reverse liver fibrosis. World Chin J Digestol 2010;18:2291-5.

[15] Huang YL, Zhou CG, Chen Y, Zhang Y, Zhang QY. The research progress of TGF/Smad signaling pathways and liver fibrosis. Pract Med J 2011;27:1883-4.

[16] Zhou W, Chen PF, Wu XL, Jiang R, Xu YH. Bone marrow mesenchymal stem cells contribute to liver fibrosis. Chin J Hepatol 2011;19:707-8.

[17] Wang ZC, Yang S, Huang JJ, Chen SL, Li QQ, Li Y. Effect of bone marrow mesenchymal stem cells on the Smad expression of hepatic fibrosis rats. Asian Pacif J Trop Med 2014;7:321-4.

[18] Henneke DR, Potter GD, Kreider JL, Yeates BF. Relationship between condition score, physical measurement, and body fat percentage in mares. Equine Vet J 1983;15:371-2.

[19] Kenney RM, Doig PA. Equine endometrial biopsy. In: Marrow D, editor. Current therapy in theriogenology: diagnosis, treatment, and prevention of reproductive diseases in small and large animals. 2nd ed. W.B. Saunders; Philadelphia; 1986. p. 723-9 (515 Ed.).

[20] Barreira A, Alves AL. Implante Autólogo de Células Mesenquimais no Tratamento da Tendinite Induzida em Eqüinos; Avaliação Clínica, ultrasonografia e Imunohistoquímica. Botucatu: Tese (Doutorado), Faculdade de Medicina Veterinária e Zootecnia, Universidade Estadual Paulista; 2005. p. 98.

[21] Swanson TD. Guide for veterinary service and judging of equestrian events. 3rd ed. Golden, CO: American Association of Equine Practioners; 1984.

[22] Mccue PM, Scoggin CF, Lindholm AF. Estrus. In: McKinnon AO, Squires EL, Vaala WE, Vrner DD, editors. Equine reproduction. 2nd ed., 179. Ames: Blackwell Publishing; 2011. p. 1716-27.

[23] Ricketts SW. Endometrial biopsy as a guide to diagnosis of endometrial pathology in the mare. J Reprod Fertil Suppl 1975;23:341-5.

[24] Maia L, Souza MV, Junior JI, Oliveira AC, Alves GE, Benjamin LA, Silva YF, Zandim BM, Moreira JC. Platelet-rich plasma in the treatment of induced tendinopathy in horses: histologic evaluation. J Equ Vet Sci 2009;29:618-26.

[25] Oshima Y, Watanabe N, Matsuda K, Takai S, Kawata M, Kubo T. Behavior of transplanted bone marrow-derived GFP mesenchymal cells in osteochondral defect as a simulation of autologous transplantations. J Histochem Cytochem 2005;53:207-16.

[26] Kern S, Eichler H, Stoeve J, Kluter H, Bieback K. Comparative analysis of mesenchymal stem cell from bone marrow, umbilical cord blood, or adipose tissue. Stem Cell 2004;24:1294-301.

[27] Zhu Y, Liu T, Song K, Fan X, Ma X, Cui Z. Adipose derived stem cell: a better stem cell than BMSC. Cell Biochem Func 2008;26:664-75.

[28] Mcsweeney PA. Characterization of monoclonal antibodies that recognize canine CD34. Blood 1998;91:1977-86.

[29] Lima-Neto JF. Isolamento, caracterização e diferenciação de células tronco embrionárias e mesenquimais de equinos. Tese (Doutorado). Universidade Estadual Paulista "Júlio de Mesquita Filho" Faculdade de Medicina Veterinária e Zootecnia. 2010:108p.

[30] Phinney DG, Prockop DJ. Concise review: mesenchymal stem/multipotent stromal cells: the state of transdifferentiation and modes of tissue repair-current views. Stem Cell 2007;23:2896-902.

[31] Ferris DJ, Frisbie DD, Kisiday JD, Mcllwraith CW, Hague BA, Major MD, Schneider RK, Zubrod CJ, Kawcak CE, Goodrich LR. Clinical outcome after intra-articular administration of bone marrow derived mesenchymal stem cells in 33 horses with stifle injury. Vet Surg 2014;43:255-65.

[32] Carrade DD, Owens SD, Galuppo LD, Vidal MA, Ferraro GL, Librach F, Buerchler S, Friedman MS, Walker NJ, Borjesson DL. Clinicopathologic findings following intra-articular injection of autologous and allogeneic placentally derived equine mesenchymal stem cells in horses. Cytotherapy 2011;13:419-30.

[33] Guest DJ, Smith MR, Allen WR. Monitoring the fate of autologous and allogeneic mesenchymal progenitor cells injected into the superficial digital flexor tendon of horses: preliminary study. Equine Vet J 2008;40:178-81.

[34] Kol A, Wood JA, Holt DD, Gillette JA, Bohannon-Worsley LK, Puchalski SM, Walker NJ, Clark KC, Watson JL, Borjesson DL. Multiple intravenous injections of allogeneic equine mesenchymal stem cells do not induce a systemic inflammatory response but do alter lymphocyte subsets in healthy horses. Stem Cell Res Ther 2015; 6:73. 
[35] Ferrer MS, Lyle SK, Paccamonti DL, Elits BE, Hosgood G, Godke RA. Persistent breeding-induced endometritis after hysteroscopic insemination in the mare. Reprod Dom Anim 2012;47:732-9.

[36] Carmo MT, Alvarenga FC, Guastali G, Maia L, Alvarenga MA. Treatment of mares with chronic uterine injury using stem cells obtained from bone marrow. Reprod Dom Anim 2012;47:591.

[37] Crovace A, Lacitignola L, De Siena R, Rossi G, Francioso E. Cell therapy for tendon repair in horses: an experimental study. Vet Res Commun 2007:31:281-3.

[38] Pacini S, Spinabella S, Trombi L, Galimberti S, Dini F, Carulicci F, Petrini M. Suspension of bone marrow-derived undifferentiaed mesenchymal stromal cells for repair of superficial digital flexor tendon in race horses. Tissue Eng 2007;13:2949-55.

[39] Wilke MM, Nydam DV, Nixon AJ. Enhanced early chondrogenesis in articular defects following arthroscopic mesenchymal stem cell implantation in an equine model. J Orthop Res 2007;25:913-25.
[40] Nixon AJ, Dahlgren LA, Haupt JL, Yeager AE, Ward DL. Effect of adipose-derived nucleated cell fractions on tendon repair in horses with collagenase-induced tendinitis. Am J Vet Res 2008 69:928-37.

[41] Carvalho AM, Alves AL, Oliveira PG, Alvarez LE, Laufer-Amorim R Hussni CA, Deffune E. Use of adipose tissue-derived mesenchymal stem cells for experimental tendinitis therapy in equines. J Equine Vet Sci 2011;31:26-34.

[42] McIlwraith CW, Frisbie DD, Rodkey WG, Kisiday JD, Werpy NM Kawcak CE, Steadman JR. Evaluation of intra-articular mesenchymal stem cells to augment healing of microfractured chondral defects. Arthroscopic 2011:27:1552-61.

[43] Del Bue M, Ricco S, Ramoni R, Conti V, Gnudi G, Grolli S. Equine adipose-tissue derived mesenchymal stem cells and platelet concentrates: their association in vitro and in vivo. Vet Res Commun 2008;32:S51-5. 